\title{
Pengaruh interaksi bokashi dan pupuk organik cair daun gamal terhadap pertumbuhan dan hasil sawi
}

\section{The interaction effect of bokashi and liquid organic fertilizer gamal leaves on growth and production of vegetable mustard}

\author{
Dorci M. Peni ${ }^{1}$, Andri P. Timung ${ }^{1 *}$, Didiana Molebila ${ }^{1}$, Emirensiana Latuan $^{1}$ \\ ${ }^{1}$ Program Studi Agribisnis, Fakultas Pertanian dan Perikanan, Universitas Tribuana Kalabahi \\ *Email korespondensi: andremorango58@gmail.com
}

Diterima: 13 Januari 2021 / Disetujui: 19 Maret 2021

\begin{abstract}
Research has been carried out on the effect of organic fertilizers on the growth and yield of mustard greens. This study aims to: 1) determine the effect of the interaction between bokashi fertilizer and liquid organic fertilizer on the growth of mustard greens, 2) the best dose of interaction between bokashi fertilizer and liquid organic fertilizer on mustard growth. This study was designed using a randomized Complete block design (RCBD) with 6 treatments and 3 replications so that there were 18 experiments. The research variables were as follows: 1) Factor I: Bokashi fertilizer consisted of no bokashi fertilizer application and 40 ton.ha-bokashi fertilizer application ${ }^{l}$. equalized to $4 \mathrm{~kg}_{\text {.petak }}{ }^{-1}$; Factor II: Liquid organic fertilizer consists of no liquid organic fertilizer, application of $50 \mathrm{Ml}$ of liquid organic fertilizer, application of $75 \mathrm{Ml}$ of liquid organic fertilizer. To see the effect of the treatment, it was analyzed using analysis of variance (ANOVA) and to see the best dose was analyzed using the Least Significant Difference (LSD). The results showed that: (1) The interaction of bokashi with liquid organic fertilizer had a significant effect on plant height, leaf area, number of leaves and wet weight; (2) The best dose of interaction between bokashi fertilizer is 40 ton.ha- ${ }^{l}$ which is interacted without liquid organic fertilizer between bokashi fertilizer and liquid organic fertilizer.
\end{abstract}

Keywords: Bokhasi, mustard, organic fertilizer, yield.

\section{ABSTRAK}

Telah dilakukan penelitian pengaruh pupuk organik terhadap pertumbuhan dan hasil sawi. Penelitian ini bertujuan untuk: 1) mengetahui pengaruh interaksi pupuk bokasi dan pupuk organik cair terhadap pertumbuhan sawi, 2) dosis terbaik interaksi pupuk bokasi dan pupuk organik cair terhadap pertumbuhan sawi. Penelitian ini didesain menggunakan Rancangan Acak Kelompok (RAK) dengan 6 perlakuan dan 3 ulangan sehingga terdapat 18 percobaan, variabel penelitian sebagai berikut: 1) Faktor I: Pupuk bokasi terdiri dari Tanpa aplikasi pupuk bokasi dan Aplikasi pupuk bokasi 40 ton.ha ${ }^{-1}$ yang disetarakan dengan 4kg.petak-1 ; Faktor II: Pupuk organik cair terdiri dari Tanpa pupuk organik cair, aplikasi pupuk organik cair 50 Ml, aplikasi pupuk organik cair 75 Ml. Untuk melihat pengaruh perlakuan dianalisis menggunakan Analisis varian (Anova) dan untuk melihat dosis terbaik dianalisis menggunakan Beda Nyata Terkecil (BNT). Hasil penelitian menunjukan bahwa: (1) Interaksi bokasi dengan pupuk organik cair berpengaruh nyata tinggi tanaman, luas daun, jumlah daun dan bobot basah; (2) Dosis terbaik interaksi pupuk bokasi sebesar 40 ton.ha ${ }^{-1}$ yang diinteraksikan dengan tanpa pupuk organik cair antara pupuk bokasi dan pupuk organik cair.

Kata kunci: Bokhasi, hasil, pupuk organik, sawi.

\section{PENDAHULUAN}

Usahatani sawi merupakan salah satu peluang agribisnis yang dapat dikembangkan di Indonesia dan di Kabupaten Alor khususnya. hal ini dapat didukung dengan tingginya permintaan sawi yang mencapai $500 \mathrm{~kg} /$ bulan di Kota Kalabahi, selain itu keadaan alam Alor yang mendukung untuk budidaya sawi, Jika di tinjau dari aspek ekonomis dan bisnisnya layak untuk dikembangkan atau diusahakan untuk memenuhi permintaan konsumen serta adanya peluang pasar. Kelayakan pengembangan budidaya sawi antara lain ditunjukan oleh adanya keunggulan komparatif kondisi wilayah tropis Indonesia yang sangat baik (Sunarjono, 2007).
Menurunnya kualitas tanah disebabkan oleh penggunaan pupuk anorganik secara terus menerus sehingga akan menyebabkan tanah menjadi padat/mengeras dan tidak responsif terhadap pupuk yang diberikan, selain itu berkurangnya suplai oksigen ke akar dan mengakibatkan menurunnya produktivitas tanaman (Yuniarti et al., 2020). Selain itu juga penggunaan pupuk anorganik yang tinggi dapat menurunkan ketersediaan unsur hara, dan salah satu bahan yang dapat digunakan untuk memperbaiki sifat- sifat tanah adalah bahan organik (Hardjowigeno, 2007).

Bokashi merupakan salah satu jenis pupuk organik yang dihasilkan dari proses fermentasi atau peragian bahan organik dengan teknologi EM4 (Effective Microorganisms 4). Penggunaan pupuk bokashi dapat memperbaiki sifat kimia, 
fisik dan biologi tanah. Penggunaan pupuk ini lebih efektif dan ramah lingkungan, serta menyediakan unsur hara bagi tanaman (menyuburkan tanah), menekan pertumbuhan gulma dan menekan populasi hama dan penyakit tanaman. Menurut Muzayyanah, (2010) kandungan hara yang terkandung dalam bokasi ialah $\mathrm{N}$ total $21,5 \%, \mathrm{P}_{2} \mathrm{O} 51,02 \%, \mathrm{~K} 1,44 \%, \mathrm{H}_{2} \mathrm{O}$ $8,50 \%$, KCL 7,60\%.

Selain bokasi terdapat juga pupuk organik cair yang merupakan larutan mudah larut berisi satu atau lebih pembawa unsur hara yang dibutuhkan tanaman. Kelebihan dari pupuk cair adalah kandungan haranya bervariasi yaitu mengandung hara makro dan mikro. Salah satu alternatif sumber bahan baku hara yang digunakan sebagai pupuk organik cair yaitu dari bahan-bahan alami yang mengandung unsur Nitrogen, diantaranya adalah daun gamal. Gamal adalah salah satu tanaman dari Famili Leguminosae yang mengandung berbagai hara esensial yang cukup tinggi bagi pemenuhan hara tanaman pada umumnya. Jaringan daun tanaman gamal mengandung $3,15 \% \mathrm{~N}, 0,22 \% \mathrm{P}, 2,65 \% \mathrm{~K}$, 1,35\% Ca, dan 0,41\% Mg (Ibrahim, 2002).

Penggunaan pupuk bokasi dan pupuk organik cair sangat bermanfaat bagi petani karena meningkatkan kualitas tanah dan pertumbuhan tanaman. Selain itu, penggunaan pupuk organik juga dapat menekan biaya produksi tanaman sawi karena bahan yang digunakan dari lingkungan sekitar, Sebagai upaya dalam perbaikan agribisnis sawi berdasarakan potensi pupuk organik terhadap pertumbuhan tanaman dan dampak ekonomisnya terhadap petani, penelitian ini bertujuan untuk: 1) Mengetahui pengaruh interaksi bokasi dengan pupuk organik cair dalam meningkatkan pertumbuhan dan hasil sawi; 2) Mengetahui dosis terbaik interaksi antara pupuk bokasi dan pupuk organik cair terhadap pertumbuhan dan hasil sawi;

\section{METODE PENELITIAN}

Penelitian ini telah dilaksanakan di kebun percontohan Universitas Tribuana Kalabahi pada bulan Juni - Agustus 2019. Penelitian ini didesain menggunakan Rancangan Acak Kelompok (RAK) dengan 6 perlakuan dan 3 ulangan sehingga terdapat 18 percobaan, variabel penelitian sebagai berikut: 1) Faktor I: Pupuk bokasi terdiri dari: Tanpa aplikasi pupuk bokasi dan Aplikasi pupuk bokasi 40 ton.ha ${ }^{-1}$ yang disetarakan dengan 4kg.petak ${ }^{-1}$; Faktor II: Pupuk organik cair terdiri dari Tanpa pupuk organik cair, aplikasi pupuk organik cair $50 \mathrm{Ml}$, aplikasi pupuk organik cair $75 \mathrm{Ml}$. Pelaksanaan penelitian berupa Persiapan (Pembuatan bokasi dan pembuatan pupuk cair), pelaksanaan (persiapan lahan, pembibitan, penanaman, pemeliharaan, panen dan pemasaran). Variabel yang diamati ialah tinggi tanaman, luas daun, jumlah daun, dan bobot basah. Untuk mengetahui pengaruh menggunakan analisis sidik ragam dan uji BNT untuk mengetahui perbedaan antar perlakuan.

\section{HASIL DAN PEMBAHASAN}

\section{Tinggi Tanaman}

\section{Tinggi tanaman 1 MST}

Analisis sidik ragam menunjukan bahwa pemberian pupuk organik cair daun gamal berpengaruh sangat nyata terhadap tinggi tanaman pada umur 1 Minggu Setelah Tanam (MST). Analisis ragam juga menjukan bahwa interaksi antara pupuk organik cair daun gamal dengan bokasi berpengaruh nyata terhadap tinggi tanaman. Namun faktor tunggal pemberian bokasi berpengaruh tidak nyata terhadap tinggi tanaman.

Pemberian pupuk bokasi berpengaruh tidak nyata terhadap tinggi tanaman pada umur 1 minggu setelah tanam. hal ini disebabkan oleh pupuk bokasi belum terdekomposisi secara sempurna sehingga hara yang terkandung dalam bokasi masih dalam bentuk organik atau masih terikat dan belum bisa diserap oleh tanaman. Menurut Utami, (2009)kandungan bahan organik mengandung banyak hara nitrogen dan laju proses terjadinya pembebasan nitrogen melalui proses mineral dari sisa-sisa bahan organik yang dibutuhkan mikroorganisme.

Tabel 1 Menjelaskan bahwa pemberian pupuk organik cair sebesar $50 \mathrm{~mL} / \mathrm{L}$ berbeda tidak nyata dengan tanpa pupuk organik caik. hal ini disebabkan oleh hara yang diberikan melalui pupuk organik cair belum mampu memenuhi kebutuhan hara tanaman pada umur 1 minggu setelah tanam. hal ini ditunjukan dengan adanya perbedaan dengan pemberian pupuk organik cair sebesar $75 \mathrm{~mL} / \mathrm{L}$ yaitu sebesar $9,08 \mathrm{~cm}$. pemberian pupuk organik cair dapat menyuplai kebutuhan hara bagi tanaman terutama nitrogen.

Tabel 1. Rataan tinggi tanaman sawi 1 MST pada berbagai dosis bokasi dan pupuk organik cair.

\begin{tabular}{|c|c|c|c|c|c|c|c|}
\hline \multirow{2}{*}{$\begin{array}{l}\text { Perlakuan } \\
\text { Tanpa aplikasi pupuk bokasi }\end{array}$} & \multicolumn{2}{|c|}{$\begin{array}{l}\text { Tanpa pupuk } \\
\text { organik cair }\end{array}$} & \multicolumn{2}{|c|}{$\begin{array}{l}\text { Pupuk organik } \\
\text { cair } 50 \mathrm{Ml}\end{array}$} & \multicolumn{2}{|c|}{$\begin{array}{c}\text { Pupuk organik } \\
\text { cair } 75 \mathrm{Ml}\end{array}$} & \multirow{2}{*}{$\frac{\text { Rerata }}{7,94}$} \\
\hline & 6,07 & $\mathrm{a}$ & 8,80 & $\mathrm{~b}$ & 8,95 & $\mathrm{~b}$ & \\
\hline Pupuk bokasi 40 ton.ha ${ }^{-1}$ & 6,60 & $\mathrm{ab}$ & 7,87 & $\mathrm{~b}$ & 9,21 & $\mathrm{~b}$ & 7,89 \\
\hline Rerata & 6,33 & $\mathrm{a}$ & 8,33 & $\mathrm{a}$ & 9,08 & $\mathrm{~b}$ & \\
\hline
\end{tabular}

Keterangan: Angka-angka yang diikuti oleh huruf yang berbeda memberikan perbedaan yang nyata berdasarkan uji lanjut BNT 5\%. 
Tabel 2. Rataan tinggi tanaman sawi 2 MST pada berbagai dosis bokasi dan pupuk organik cair.

\begin{tabular}{|c|c|c|c|c|c|c|c|}
\hline Perlakuan & \multicolumn{2}{|c|}{$\begin{array}{l}\text { Tanpa pupuk } \\
\text { organik cair }\end{array}$} & \multicolumn{2}{|c|}{$\begin{array}{l}\text { Pupuk organik } \\
\text { cair } 50 \mathrm{Ml}\end{array}$} & \multicolumn{2}{|c|}{$\begin{array}{c}\text { Pupuk organik } \\
\text { cair } 75 \mathrm{Ml}\end{array}$} & Rerata \\
\hline Tanpa aplikasi pupuk bokasi & 28,20 & $\mathrm{a}$ & 31,60 & $\mathrm{ab}$ & 41,00 & $\mathrm{~b}$ & 33,60 \\
\hline Pupuk bokasi 40 ton.ha ${ }^{-1}$ & 30,17 & $\mathrm{ab}$ & 28,47 & $\mathrm{a}$ & 38,00 & $\mathrm{~b}$ & 32,21 \\
\hline Rerata & 29,18 & $\mathrm{a}$ & 30,03 & $\mathrm{a}$ & 39,5 & $\mathrm{~b}$ & \\
\hline
\end{tabular}

Keterangan: Angka-angka yang diikuti oleh huruf yang berbeda memberikan perbedaan yang nyata berdasarkan uji lanjut BNT 5\%.

Tabel 3. Rataan tinggi tanaman sawi 3 MST pada berbagai dosis bokasi dan pupuk organik cair.

\begin{tabular}{|c|c|c|c|c|}
\hline Perlakuan & $\begin{array}{c}\text { Tanpa pupuk } \\
\text { organik cair }\end{array}$ & $\begin{array}{c}\text { Pupuk organik } \\
\text { cair } 50 \mathrm{Ml}\end{array}$ & $\begin{array}{c}\text { Pupuk organik } \\
\text { cair } 75 \mathrm{Ml}\end{array}$ & Rerata \\
\hline Tanpa aplikasi pupuk bokasi & 39,20 & 42,13 & 45,73 & 33,60 \\
\hline Pupuk bokasi 40 ton.ha ${ }^{-1}$ & 39,33 & 42,10 & 46,27 & 32,21 \\
\hline Rerata & 39,27 & 42,12 & 46 & \\
\hline
\end{tabular}

Keterangan: Angka-angka yang diikuti oleh huruf yang berbeda memberikan perbedaan yang nyata berdasarkan uji lanjut BNT 5\%.

Oviyanti et al., (2016) menyatakan bahwa daun gamal jika dijadikan pupuk organik mempunyai kandungan nitrogen lebih tinggi sehingga sangat cocok jika diaplikasikan pada tanaman yang menghasilkan bagian vegetatif sebagai bagian tanaman yang dipanen. Tanaman sawi merupakan tanaman indikator yang mampu memberikan respons lebih baik serta kebutuhan haranya dapat terpenuhi oleh bentuk dan keragaman hara pupuk organik daun gamal tersebut.

Interaksi antara pupuk organik cair dengan bokasi berpengaruh nyata terhadap pertumbuhan tinggi tanaman pada umur 1 minggu setelah tanam. Tabel 1 menjelaskan bahwa tinggi tanaman terendah terdapat pada perlakuan tanpa pupuk organik cair dan tanpa bokasi. hal ini disebabkan oleh tidak adanya sumbangan hara dari luar sehingga pertumbuhan menjadi terhambat. sedangkan tinggi tanaman tertinggi terdapat pada perlakuan $75 \mathrm{~mL} / \mathrm{L}$ yang diinteraksikan dengan bokasi sebesar 40 ton $\mathrm{ha}^{-1}$. namun berbeda tidak nyata dengan perlakuan lainnya. hal ini disebabkan oleh pupuk organik cair dan bokasi yang diberikan mampu menyumbang hara terutama nitrogen bagi pertumbuhan tanaman. Zubachtirodin dan Subandi (2008) juga menyatakan bahwa tinggi tanaman dipengaruhi oleh pemberian nitrogen yang dapat meningkatkan tinggi tanaman sampai $35 \mathrm{~cm}$ lebih tinggi dibanding tanaman yang tidak diberi nitrogen.

\section{Tinggi tanaman 2 MST}

Analisis sidik ragam menunjukan pemberian pupuk cair dan interaksi antara pupuk organik cair daun gamal dan bokasi berpengaruh sangat nyata hal ini disebabkan karena kandungan nitrogen pada pupuk cair sangat tinggi sehingga sangat berpengaruh terhadap tinggi tanaman, sedangkan pemberian bokasi berpengaruh tidak nyata terhadap pertumbuhan tinggi tanaman pada umur 2 MST.

Pemberian pupuk bokasi dan pupuk cair sebanyak 75 $\mathrm{mL} / \mathrm{L}$ dan perlakuan tanpa pemberian pupuk bokasi dan pupuk cair sebanyak $75 \mathrm{~mL} / \mathrm{L}$ sangat berbeda nyata terhadap perlakuan yang lain. hal ini disebabkan oleh pupuk organik cair daun gamal memiliki kandungan unsur hara $\mathrm{N}, \mathrm{P}, \mathrm{K}, \mathrm{Ca}$, dan $\mathrm{Mg}$ yang memiliki peran tersediri bagi tanaman dalam proses metabolisme tanaman. Kecukupan unsur hara $\mathrm{N}$ akan menunjukan pertumbuhan vegetatif lebih baik dibandingkan tanaman yang kekurangan unsur hara. Sado, (2016) menyatakan bahwa pupuk organik cair gamal berpengaruh terhadap tanaman sawi, hasil penelitian ini menunjukan bahwa pupuk organik cair daun gamal dengan konsentrasi $30 \%$ memberikan respon yang paling besar dan berpengaruh terhadap jumlah daun,luas daun dan tinggi tanaman.

\section{Tinggi tanaman 3 MST}

Analisis sidik ragam menunjukan pemberian pupuk cair daun gamal berpengaruh sangat nyata terhadap tinggi tanaman sawi. Sedangkan pemberian bokasi faktor tunggal dan interaksi antara bokasi dengan pupuk organik cair pada umur 3 MST berpengaruh tidak nyata pada tinggi tanaman.

Bemberian bokasi berpengaruh tidak nyata terhadap tinggi tanaman pada umur 3 MST hal ini disebakan oleh bahan bahan yg digunakan dalam pembuatan bokasi blum terurai dengan baik.pemberian pupuk organik cair daun gamal sebanyak $50 \mathrm{~mL} / \mathrm{L}$ berbeda nyata dengan tanpak perlakuan pupuk organik cair daun gamal .namun berbeda tidak nyata dengan perlakuan pupuk organik cair sebesar $75 \mathrm{~mL} / \mathrm{L}$ hal ini disebabkan oleh kebutuhan hara oleh tanaman telah tercukupi dengan penambahan pupuk cair organik daun gamal sebesar $50 \mathrm{~mL} / \mathrm{L}$ sehingga dilakukan penambahan pupuk tidak berbeda nyata. Hal ini sesuai dengan Pardosi et al., (2014) menyatakan bahwa kelebihan pupuk organik cair adalah unsur hara yang dikandungnya lebih cepat tersedia dan mudah diserap akar tanaman selain dengan cara disiramkan pupuk cair dapat digunakan langsung dengan cara disemprotkan pada daun atau batang tanaman. interaksi antara bokasi dengan pupuk organik cair daun gamal berpengaruh tidak nyata terhadap tinggi tanaman hal ini disebabkan oleh unsur hara yang terdapat di dalam tanah msi mampu untuk menyuplai hara terhadap terhadap pertumbuhan sawi. pemberian bokasi sebesar 40 ton-ha ${ }^{-1}$ berbeda nyata dengan perlakuan tanpak bokasi hal ini disebabkan oleh metabolisme yang terdapat didalam campuran bahan bahan bokasi sudah terurai dengan baik sehingga. dalam kondisi kondisi tanaman 
cukup akan unsur hara maka laju fotosintesis dalam memproduksi asimilat semakin meningkat hal serupa telah dikemukakan oleh Murmayani, (2020)pemberian bokasi pada tanaman sawi secara umum memberikan respon yang baik terhadap pertumbuhan sawi yang meliputi tinggi tanaman jumlah daun. Pemberian bokasi dapat menambah kandungan humus dan memperbaiki sifat fisik kimia dan biologi tanah.

\section{Luas Daun}

\section{Luas daun 1 MST}

Analisis sidik ragam menunjukan interaksi antara pupuk cair degan bokasi berpengaruh sangat nyata terhadap luas daun pada umur 1 MST hal yang sama juga pada faktor tunggal pupuk bokasi.

Interaksi antara pupuk organik cair daun gamal dengan bokasi memberikan hasil terendah pada perlakuan tanpak pupuk bokasi dengan perlakuan tanpak pupuk organik cair daun gamal yaitu sebesar 11,47 $\mathrm{cm}^{2}$. Hal ini disebabkan oleh tidak ada sumbangan pupuk dari luar sehingga perkembangan luas daun tidak sebesar perlakuan lainnya. Menurut Jusuf, (2006) bahwa dibutuhkan usaha maksimal untuk menggali dan memanfaatkan potensi bahan organik yang tersedia secara alami diantaranya dapat berupa pemanfaatan tanaman leguminoceae sebagai bentuk organik yang siap dan mampu berperan sebagai suplayer hara secara dan tepat disamping perbaikan fisik dan biologi tanah. Sedangkan interaksi antara pupuk organik cair daun gamal sebesar $75 \mathrm{~mL} / \mathrm{L}$ dengan bokasi sebesar 40 ton ha $^{-1}$ memberikan hasil tertinggi yaitu sebesar $22.20 \mathrm{~cm}^{2}$, perlakuan ini merupakan perlakuan tertinggi sehingga sumbangan unsur hara yang diberikan ke tanah untuk tanaman lebih besar jika dibandingkan dengan perlakuan lainnya

\section{Luas daun 2 MST}

Analisis sidik ragam menunjukan bahwa interaksi antara bokasi dan pupuk organik cair daun gamal berpengaruh nyata terhadap luas daun pada umur 1 MST. Pemberian pupuk organik cair daun gamal faktor tunggal berpengaruh sangat nyata terhadap luas daun 2 MST sedangkan pupuk bokasi faktor tunggal berpengaruh tidak nyata terhadap luas daun 2 MST.
Analisis sidik ragam menunjukan bahwa pemberian pupuk organik cair daun gamal berpengaruh tidak nyata. Hal ini disebabkan oleh pupuk yang diberikan berupa pupuk organik cair daun gamal pada dosis yang diberikan pada minggu pertama telah mampu memenuhi kebutuhan hara sehingga pemberian kedua tidak berpengaruh, sejalan dengan itu menurut para ahli Sarief, (1986)mengatakan bahwa pupuk organik cair daun gamal memiliki kandungan nitrogen yang cukup tinggi sehingga mampu mensuplai ketrsediaan unsur hara dalam tanah, dan dengan tersedianya unsur hara dalam jumlah yang cukup pada saat pertumbuhan vegetatif maka proses fotosintesis akan berjalan aktif sehingga pembelahan, pemanjangan, dan diferensiasi sel akan berjalan dengan baik.

Tabel 5 menjelaskan bahwa pemberian bokasi sebesar 40 ton ha $^{-1}$ berbeda nyata dengan perlakuan tanpak pemberian bokasi. Pemberian bokasi pada tanah dapat memperbaiki sifat fisik, kimia, dan biologi tanah. Dengan adanya perbaikan sifat tanah maka dapat menunjang ketersediaan hara bagi tanaman. Pemberian pupuk organik pada lahan pertanian sangat penting dalam menjaga kesuburan tanah dan pertumbuhan tanaman. Fortunasari (2018) menjelaskan bahwa hasil peruraian bahan organik yang ditambahkan kedalam tanah dapat mempengaruhi pertumbuhan tanaman melalui pengaruhnya pada sifat fisik, kimia, dan biologis tanah

Tabel 5 menjelaskan bahwa perlakuan interaksi antara tanpak bokasi dengan perlakuan tanpak perlakuan pupuk organik cair daun gamal memberikan luas daun terendah dan berbeda tidak nyata dengan perlakuan bokasi sebesar 40 ton $\mathrm{ha}^{-1}$ yang diinteraksikan dengan pupuk organik cair daun gamal sebesar $50 \mathrm{~mL} / \mathrm{L}$. sedangkan daun terluas terdapat padaperlakuan pupuk organik cair sebesar $75 \mathrm{~mL} / \mathrm{L}$ yang diinteraksikan dengan perlakuan tanpak bokasi namun berbeda tidak nyata dengan perlakuan lainnya. Hal ini disebabkan oleh adanya sumbangan nitrogen lewat pupuk cair yag diberikan pada sawi. Semakin banyak jumlah pupuk yang diberikan maka semakin tinggi suplai hara pada tanaman. Hal ini sejalan dengan Tabun et al., (2017) menyatakan bahwa pupuk bokasi dapat memperbaiki sifat fisik, kimia, dan biologi tanah meningkatkan produksi tanaman dan menjaga kestabilan produksi tanaman serta menghasilkan kualitas dan kuantitas hasil pertanian yang berwawasan lingkungan.

Tabel 4. Rataan luas daun sawi 1 MST pada berbagai dosis bokasi dan pupuk organik cair.

\begin{tabular}{cccccccc}
\hline Perlakuan & \multicolumn{2}{c}{$\begin{array}{c}\text { Tanpa pupuk } \\
\text { organik cair }\end{array}$} & $\begin{array}{c}\text { Pupuk organik } \\
\text { cair 50 Ml }\end{array}$ & $\begin{array}{c}\text { Pupuk organik } \\
\text { cair 75 Ml }\end{array}$ & Rerata \\
\hline Tanpa aplikasi pupuk bokasi & 11,47 & a & 18,73 & bc & 19,00 & bc & $16,40 \mathrm{a}$ \\
Pupuk bokasi 40 ton.ha ${ }^{-1}$ & 16,87 & b & 19,20 & bc & 22,20 & $\mathrm{c}$ & $19,42 \mathrm{~b}$ \\
\hline Rerata & 14,17 & a & 18,97 & a & 20,60 & b & \\
\hline
\end{tabular}

Keterangan: Angka-angka yang diikuti oleh huruf yang berbeda memberikan perbedaan yang nyata berdasarkan uji lanjut BNT 5\%. 
Tabel 5. Rataan luas daun sawi 2 MST pada berbagai dosis bokasi dan pupuk organik cair.

\begin{tabular}{|c|c|c|c|c|c|c|c|}
\hline \multirow{2}{*}{$\begin{array}{l}\text { Perlakuan } \\
\text { Tanpa aplikasi pupuk bokasi }\end{array}$} & \multicolumn{2}{|c|}{$\begin{array}{l}\text { Tanpa pupuk } \\
\text { organik cair }\end{array}$} & \multicolumn{2}{|c|}{$\begin{array}{c}\text { Pupuk organik } \\
\text { cair } 50 \mathrm{Ml}\end{array}$} & \multicolumn{2}{|c|}{$\begin{array}{l}\text { Pupuk organik } \\
\text { cair } 75 \mathrm{Ml}\end{array}$} & \multirow{2}{*}{$\begin{array}{l}\text { Rerata } \\
136,20\end{array}$} \\
\hline & 124,93 & $\mathrm{a}$ & 138,33 & $\mathrm{bc}$ & 145,33 & $\mathrm{c}$ & \\
\hline Pupuk bokasi 40 ton.ha ${ }^{-1}$ & 136,93 & $\mathrm{~b}$ & 131,67 & $\mathrm{ab}$ & 141,13 & $\mathrm{bc}$ & 136,58 \\
\hline Rerata & 130,93 & & 135,00 & & 143,23 & & \\
\hline
\end{tabular}

Keterangan: Angka-angka yang diikuti oleh huruf yang berbeda memberikan perbedaan yang nyata berdasarkan uji lanjut BNT 5\%.

Tabel 6. Rataan Luas Daun sawi 3 MST pada berbagai dosis bokasi dan pupuk organik cair.

\begin{tabular}{lcccccccc}
\hline \multicolumn{1}{c}{ Perlakuan } & \multicolumn{2}{c}{ Tanpa pupuk } & \multicolumn{2}{c}{$\begin{array}{c}\text { Pupuk organik } \\
\text { organik cair }\end{array}$} & $\begin{array}{c}\text { Pupuk organik } \\
\text { cair 50 Ml }\end{array}$ & cair 75 Ml & Rerata \\
\hline Tanpa aplikasi pupuk bokasi & 136,60 & ab & 147,93 & ab & 125,07 & a & 136,5 & a \\
Pupuk bokasi 40 ton.ha ${ }^{-1}$ & 145,27 & ab & 153,87 & b & 157,73 & b & 152,3 & b \\
\hline Rerata & 140,9 & & 150,9 & & & & &
\end{tabular}

Keterangan: Angka-angka yang diikuti oleh huruf yang berbeda memberikan perbedaan yang nyata berdasarkan uji lanjut BNT 5\%.

Tabel 7. Rataan jumlah Daun sawi 1 MST pada berbagai dosis bokasi dan pupuk organik cair.

\begin{tabular}{|c|c|c|c|c|c|c|c|}
\hline \multirow{2}{*}{$\begin{array}{l}\text { Perlakuan } \\
\text { Tanpa aplikasi pupuk bokasi }\end{array}$} & \multicolumn{2}{|c|}{$\begin{array}{l}\text { Tanpa pupuk } \\
\text { organik cair }\end{array}$} & \multicolumn{2}{|c|}{$\begin{array}{c}\text { Pupuk organik } \\
\text { cair } 50 \mathrm{Ml}\end{array}$} & \multicolumn{2}{|c|}{$\begin{array}{c}\text { Pupuk organik } \\
\text { cair } 75 \mathrm{Ml}\end{array}$} & \multirow{2}{*}{$\begin{array}{c}\text { Rerata } \\
4,23\end{array}$} \\
\hline & 3,53 & $\mathrm{a}$ & 4,37 & $\mathrm{~b}$ & 4,80 & $\mathrm{~b}$ & \\
\hline Pupuk bokasi 40 ton.ha ${ }^{-1}$ & 4,53 & $\mathrm{~b}$ & 4,73 & $\mathrm{~b}$ & 4,80 & $\mathrm{~b}$ & 4,69 \\
\hline Rerata & 4.03 & $\mathrm{a}$ & 4,55 & $a b$ & 4,8 & $\mathrm{~b}$ & \\
\hline
\end{tabular}

Keterangan: Angka-angka yang diikuti oleh huruf yang berbeda memberikan perbedaan yang nyata berdasarkan uji lanjut BNT 5\%.

\section{Luas Daun 3 MST}

Analisis sidik ragam menunjukan perlakuan interaksi antara bokasi dan perlakuan pupuk organik cair daun gamal berpengaruh sangat nyata terhadap luas daun umur 3 MST. Pemberian bokasi faktor tunggal berpengaruh nyata terhadap luas daun pada umur 3 MST sedangkan pemberian pupuk organik cair daun gamal faktor tunggal berpengaruh tidak nyata terhadap luas daun pada umur 3 MST.

Tabel 6 menjelaskan bahwa interaksi antara bokasi sebesar 40 ton $\mathrm{ha}^{-1}$ dengan pupuk organik cair sebesar 75 $\mathrm{mL} / \mathrm{L}$ memberikan luas daun tertinggi yaitu $157.75 \mathrm{~cm}^{2}$ dan berbeda tidak nyata dengan perlakuan lainnya. Sedangkan perlakuan dengan luas daun terendah ialah perlakuan tanpak bokasi dengan perlakuan pupuk organik cair daun gamal sebesar $75 \mathrm{~mL} / \mathrm{L}$. hal ini dipengaruhi oleh pada saat tanaman berumur 3 MST terdapat serangan hama berupa kutu putih sehingga pertumbuhannya menjadi terhambat.

\section{Jumlah Daun}

\section{Jumlah daun 1 MST}

Analisis sidik ragam menunjukan bahwa interaksi antara pupuk organik cair berpengaruh sangat nyata terhadap peningkatan jumlah daun sedangkan pada faktor tunggal pupuk organik cair daun gamal dan faktor tunggal bokasi berpengaruh nyata.
Tabel 7 menunjukan bahwa pemberian bokasi sebesar 40 ton $\mathrm{ha}^{-1}$ berbeda nyata dengan perlakuan tanpa bokasi. Hal ini disebabkan oleh bokasi yang diberikan mampu memperbaiki sifat tanah Hardjowigeno, (2007) menjelaskan bahwa bahan organik dapat memperbaiki sifat -sifat tanah seperti sifat fisik, kimia, dan biologi tanah apabila sifat tanah baik maka sangat berperan dalam penyediaan unsur hara.

Pemberian pupuk organik cair daun gamal sebanyak $50 \mathrm{~mL} / \mathrm{L}$ dan $75 \mathrm{~mL} / \mathrm{L}$ memberikanjumlah daun terbanyak dibandingkan dengan yang tidak diberikan bokasi dan pupuk cair. Pada perlakuan pupuk cair $75 \mathrm{~mL} / \mathrm{L}$ menunjukan jumlah daun yang sama hal ini disebabkan karena lahan yang digunakan untuk penelitian merupakan lahan yang sudah pernah dipakai sehingga kandungan unsur hara yang ada pada lahan tersebut masih tersedia untuk kebutuha tanaman sawi hal ini bisa dapat dilihat pada hasil penelitian tnpak perlakuan. Tanaman pada perlakuan tanpak bokasi dan diberikan bokasi yang diberikan pupuk organik cair sebanyak $75 \mathrm{~mL} / \mathrm{L}$ memiliki daun relatf lebih banyak, hal ini karena petumbuhan jumlah daun dipengaruhi oleh kandungan nitrogen dan unsur hara yang seimbang pada tanaman. Unsur hara nitrogen sangat berperan pada pertumbuhan vegetatif tanama yang ditunjukan dengan pertumbuhan panjang terutama pada daun dan batang. 
Tabel 8. Rataan jumlah daun sawi 2 MST pada berbagai dosis bokasi dan pupuk organik cair.

\begin{tabular}{|c|c|c|c|c|c|c|c|}
\hline \multirow{2}{*}{$\begin{array}{l}\text { Perlakuan } \\
\text { Tanpa aplikasi pupuk bokasi }\end{array}$} & \multicolumn{2}{|c|}{$\begin{array}{l}\text { Tanpa pupuk } \\
\text { organik cair }\end{array}$} & \multicolumn{2}{|c|}{$\begin{array}{c}\text { Pupuk organik } \\
\text { cair } 50 \mathrm{Ml}\end{array}$} & \multicolumn{2}{|c|}{$\begin{array}{c}\text { Pupuk organik } \\
\text { cair } 75 \mathrm{Ml}\end{array}$} & Rerata \\
\hline & 10,13 & $\mathrm{a}$ & 13,40 & $\mathrm{e}$ & 12,60 & $\mathrm{~d}$ & $12,04 \mathrm{~d}$ \\
\hline Pupuk bokasi 40 ton.ha $^{-1}$ & 12,53 & $\mathrm{~d}$ & 10,60 & $\mathrm{~b}$ & 11,80 & $c$ & $11,64 \mathrm{c}$ \\
\hline Rerata & 11,333 & $\mathrm{a}$ & 12 & $\mathrm{~b}$ & 12,2 & $\mathrm{c}$ & $12,2 \mathrm{c}$ \\
\hline
\end{tabular}

Keterangan: Angka-angka yang diikuti oleh huruf yang berbeda memberikan perbedaan yang nyata berdasarkan uji lanjut BNT 5\%.

Tabel 9. Rataan jumlah daun sawi 3 MST pada berbagai dosis bokasi dan pupuk organik cair.

\begin{tabular}{|c|c|c|c|c|c|c|c|c|}
\hline \multirow{2}{*}{$\begin{array}{l}\text { Perlakuan } \\
\text { Tanpa aplikasi pupuk bokasi }\end{array}$} & \multicolumn{2}{|c|}{$\begin{array}{l}\text { Tanpa pupuk } \\
\text { organik cair }\end{array}$} & \multicolumn{2}{|c|}{$\begin{array}{l}\text { Pupuk organik } \\
\text { cair } 50 \mathrm{Ml}\end{array}$} & \multicolumn{2}{|c|}{$\begin{array}{l}\text { Pupuk organik } \\
\text { cair } 75 \mathrm{Ml}\end{array}$} & \multicolumn{2}{|c|}{ Rataan } \\
\hline & 18,33 & $\mathrm{a}$ & 29,93 & $\mathrm{c}$ & 20,13 & $\mathrm{~b}$ & 21,13 & $\mathrm{~b}$ \\
\hline Pupuk bokasi 40 ton.ha ${ }^{-1}$ & 18,73 & $\mathrm{a}$ & 20,47 & $\mathrm{~b}$ & 20,00 & $\mathrm{~b}$ & 19,73 & $\mathrm{~b}$ \\
\hline Rerata & 18,53333 & $\mathrm{a}$ & 22,7 & $\mathrm{c}$ & 20,06667 & $\mathrm{~b}$ & & \\
\hline
\end{tabular}

Keterangan: Angka-angka yang diikuti oleh huruf yang berbeda memberikan perbedaan yang nyata berdasarkan uji lanjut BNT 5\%.

Tabel 10. Rataan bobot basah pada berbagai dosis bokasi dan pupuk organik cair.

\begin{tabular}{|c|c|c|c|c|c|c|c|}
\hline \multirow{2}{*}{$\begin{array}{l}\text { Perlakuan } \\
\text { Tanpa aplikasi pupuk bokasi }\end{array}$} & \multicolumn{2}{|c|}{$\begin{array}{l}\text { Tanpa pupuk } \\
\text { organik cair }\end{array}$} & \multicolumn{2}{|c|}{$\begin{array}{c}\text { Pupuk organik } \\
\text { cair } 50 \mathrm{Ml}\end{array}$} & \multicolumn{2}{|c|}{$\begin{array}{l}\text { Pupuk organik } \\
\text { cair } 75 \mathrm{Ml}\end{array}$} & \multirow{2}{*}{$\begin{array}{r}\text { Rerata } \\
619,00\end{array}$} \\
\hline & 512,67 & $\mathrm{a}$ & 654,67 & $\mathrm{~b}$ & 689,67 & $\mathrm{~b}$ & \\
\hline Pupuk bokasi 40 ton.ha-1 & 606,00 & $\mathrm{~b}$ & 682,33 & $\mathrm{~b}$ & 721,80 & $\mathrm{~b}$ & 670,04 \\
\hline Rerata & 559,333 & $\mathrm{a}$ & 668,5 & $\mathrm{a}$ & 705,733 & $\mathrm{~b}$ & \\
\hline
\end{tabular}

Keterangan: Angka-angka yang diikuti oleh huruf yang berbeda memberikan perbedaan yang nyata berdasarkan uji lanjut BNT 5\%.

\section{Jumlah Daun 2 MST}

Analisis sidik ragam menunjukan bahwa pemberian bokasi faktor tunggal dan perubahan pupuk organik cair daun gamal berpengaruh sangat nyata terhadap jumlah daun pada umur 2 minggu setelah tanam. Hal yang sama juga terjadi pada pemberian bokasi yang diinteraksikan dengan pupuk organik cair daun gamal yang berpengaruh sangat nyata terhadap peningkatan jumlah daun sawi.

Tabel 8 menjelaskan bahwa pemberian pupuk organik cair berbeda nyata pada setiap taraf perlakuan yang dicobakan. Hal ini dikarenakan adanya unsur hara yang disumbangkan lewat pupuk organik cair. Hardjowigeno, (2007)menyatakan bahwanitrogen juga mendorong pertumbuhan yang cepat termasuk perkembangan daun, batang lebih besar dan berwarna hijau tua serta mendorong pertumbuhan vegetatif diatas tanah.

Pemberian bokasi tanpa perlakuan memberikan hasil tertinggi jika dibandingkan dengan perlakuan bokasi 40 ton. $\mathrm{Ha}^{-1}$. Hal ini dikarenakan hara yang terkandung dalam tanah digunakan Mickro Oraganisme sebagai energi untuk menghancurkan bahan Organik. Atmojo, (2003) menyatakan bahwa perkembangan micro organisme membutuhkan hara untuk kelansungan hidupnya terutama Nitrogen.

Tabel 8 menjelaskan bahwa perlakuan tanpa bokasi yang diinteraksikan dengan perlakuan tanpa pupuk organik cair daun gamal memiliki jumlah daun tersedikit yaitu 10, 13 daun dan berbeda nyata dengan perlakuan lainnya. Sedangkan jumlah daun tertinggi terdapat pada perlakuan tanpa bokasi dan diinteraksikan dengan perlakuan pupuk organik cair daun gamal sebesar $50 \mathrm{ml} /$ liter. Hal ini disebabkan oleh kadar pupuk organik cair yang diberikan secara jelas mampu merangsang proses metabolisme sel yang terjadi pada jaringan meristematis pada titik daun tumbuh. Komponen organik pupuk cair daun gamal seperti $\mathrm{P}, \mathrm{K}$, dan terutama yang cukup mampu bekerja sama untuk merangsang pertumbuan tanaman karna komponen tersebut terus dimineralisasi yang menyebabkan berbagai unsur yang ada didalam proses ini terlepas secara bebas berangsur- angsur sehingga mampu dimanfaatkan tanaman sebagai makanan.

\section{Jumlah Daun 3 Minggu setelah Tanam.}

Analisis sidik ragam menunjukan bahwa pemberian pupuk organis cair daun gamal yang diinteraksikan dengan bokasi berpengaruh nyata terhadap peningkatan jumlah daun sawi pada umur 3 minggu setelah tanam. Hal yang sama juga terjadi pada faktor tunggal bokasi dan faktor tunggal pupuk organik cair daun gamal.

Tabel 9 menjelaskan bahwa jumlah tanaman terendah terdapat pada perlakuan tanpa bokasi yang diinteraksikan dengan pupuk organik cair daun gamal, yaitu 18,33. Perlakuan ini berbeda tidak nyata dengan perlakuan bokasi tanpa 40 Ton. $\mathrm{Ha}^{-1}$ yang diinteraksikan dengan perlakuan tanpa pupuk organik cair daun gamal. Jumlah daun terbanyak terdapat pada perlakuan tanpa bokasi yang diinteraksikan dengan perlakuan pupuk organik cair daun gamal sebesar 50 $\mathrm{mL} / \mathrm{L}$ yaitu 24,39 daun dan berbeda nyata dengan perlakuan lainnya. Hal ini disebabkan oleh hara yang disumbangkan telah mencukupi kebutuhan tanaman sehingga dosis pupuk ditingkatkan tidak dapat meningkatkan pertumbuhan tanaman. 
Pemberian pupuk organik cair daun gamal memberikan jumlah daun tertinggi terdapat pada perlakuan pupuk organik cair daun gamal yaitu sebesar 22,7 dan berbeda tidak nyata dengan perlakuan pupuk organik cair daun gamal lain. Pemberian bokasi sebesar 40 ton. $\mathrm{Ha}^{-1}$ memberikan hasil terendah jika dibandingkan dengan perlakuan tanpa bokasi. Hal ini disebabkan bokasi mengandung sejumlah unsur hara dan bahan organik yang berperan dalam memperbaiki sifat fisik kimia dan biologi tanah. Ketersediaan hara dalam tanah, Struktur tanah dan tata udara tanah yang baik sangat mempengaruhi pertumbuhan dan perkembangan akar tanaman dalam menyerap unsur hara. Perkembangan sistem perakaran yang baik sangat menentukan pertumbuhan Vegetatif tanaman yang pada akhirnya menentukan pula fase reproduksi dan hasil tanam.

\section{Bobot basah}

Analisis sidik ragam menunjukan perlakuan pupuk cair untuk berat basah sangat berbeda nyata terhadap perlakuan pupuk cair dan bokasi.

Berat basah tanaman sawi yang diukur pada saat panen untuk perlakuan pupuk bokasi dan Pupuk cair $(75 \mathrm{~mL} / \mathrm{L})$ menunjukan berat basah yaitu 721,80 gr dibandingan dengan perlakuan yang lain, tetapi tidak berbeda nyata dengan perlakuan tanpa bokasi dengan pupuk cair $(75 \mathrm{~mL} / \mathrm{L})$ hal ini dapat disebabkan karena pada lahan tersebut sudah pernah ditanaman sehingga unsur hara masih tersedia untuk pertumbuhan tanaman. Hal lain dapat diduga karena faktor lingkungan seperti cahaya dan jumlah air pada saat penyiraman.

Ketersediaan unsur hara pada tanaman sawi merupakan salah satu faktor yang menunjuang pertumbuhan tanaman. Menurut penelitian Sabri, (2017) Hasil penelitian menunjukkan bahwa perlakuan dengan bokashi memberikan respon baik terhadap pertumbuhan tanaman dalam hal tinggi tanaman dan jumlah daun sedangkan produksi tanaman meberikan berat basah tanaman sawi yang lebih baik terhadap kontrol. Semakin besar pupuk organik yang diberikan maka semakin besar pula bobot tanaman yang akan dihasilkan karena mineral-mineral yang terkandung dalam tanah beserta unsur haranya akan diserap dan di edarkan ke seluruh tubuh tanaman dan menjadi asupan energi dalam pertumbuhan.

\section{KESIMPULAN}

Interaksi bokasi dengan pupuk organik cair berpengaruh nyata tinggi tanaman, luas daun, jumlah daun dan bobot basah. Dosis terbaik interaksi pupuk bokasi sebesar 40 ton.ha $^{-1}$ yang diinteraksikan dengan tanpa pupuk organik cair antara pupuk bokasi dan pupuk organik cair.

\section{DAFTAR PUSTAKA}

Atmojo, S. W. (2003). Peranan bahan organik terhadap kesuburan tanah dan upaya pengelolaannya. Pidato Pengukuhan Guru Besar Ilmu Kesuburan Tanah.
Fakultas Pertanian, Universitas Sebelas Maret, Surakarta.

Hardjowigeno, S. (2007). . Jakarta: Ilmu tanah. Akademika Pressindo.

Ibrahim, B. (2002). Intergrasi Jenis Tanaman Pohon Leguminosae Dalam Sistem Budidaya Pangan Lahan Kering Dan Pengaruhnya Terhadap Sifat Tanah, Erosi, Dan Produktifitas Lahan. Disertasi. Program Pasca Sarjana Universitas Hasanuddin, Makassar.

Jusuf, L. (2006). Potensi daun gamal sebagai bahan pupuk organik cair melalui perlakuan fermentasi. Jurnal Agrisistem, 2(1), 5-16.

Muzayyanah, M. (2010) Pengaruh bokashi kulit buah kakao terhadap pertumbuhan dan produksi sawi (Brassica juncea 1.). Jurnal Ilmiah Agrotani.

Oviyanti, F., Syarifah, S., \& Hidayah, N. (2016). Pengaruh pemberian pupuk organik cair daun gamal (Gliricidia sepium (Jacq.) Kunth ex Walp.) terhadap pertumbuhan tanaman sawi (Brassica juncea L.). Jurnal Biota, 2(1), 61-67.

Pardosi, A.H., Irianto, Mukhsin. (2014). Respons Tanaman Sawi terhadap Pupuk Organik Cair Limbah Sayuran pada Lahan Kering Ultisol. Pros. Semin. Nas. Lahan Suboptimal 2014.

Sabri, Y. (2017). Pengaruh Pemberian Pupuk Organik Cair dari Sabut Kelapa dan Bokashi Cair dari Kotoran Ayam terhadap Pertumbuhan Tanaman Sawi Caisim (Brassica juncea L.). Jurnal Pertanian UMSB: Penelitian dan Kajian Ilmiah Bidang Pertanian, 1(1).

Sado, R. I. (2016) Pengaruh pemberian pupuk cair daun gamal (Gliricidia sepium) terhadap pertumbuhan tanaman sawi caisim (Brassica juncea L.).

Sarief, E. S. (1986). Kesuburan dan pemupukan tanah pertanian. Pustaka Buana. Bandung, 182.

Sunarjono, H., 2007. Bertanaman 30 jenis sayuran. Penebar Swadaya Jkt. 184.

Tabun, A. C., Ndoen, B., Leo-Penu, C. L., Jermias, J. A., Foenay, T. A., \& Ndolu, D. A. (2017). Pemanfaatan limbah dalam produksi pupuk bokhasi dan pupuk cair organik di desa tuatuka kecamatan kupang timur. Jurnal Pengabdian Masyarakat Peternakan, 2(2).

Utami, S. (2009). Kemelimpahan jenis gulma tanaman wortel pada sistem pertanian organik. BIOMA, 11(2), 54-58. 
Yuniarti, A., Solihin, E., \& Putri, A. T. A. (2020). Aplikasi pupuk organik dan $\mathrm{N}, \mathrm{P}, \mathrm{K}$ terhadap $\mathrm{pH}$ tanah, $\mathrm{P}$ tersedia, serapan $\mathrm{P}$, dan hasil padi hitam (Oryza sativa L.) pada inceptisol. Kultivasi, 19(1), 1040-1046. 